DOI: $\underline{10.47524 / \mathrm{j} 1 \mathrm{st} . \mathrm{v} 2 \mathrm{i} 2.6}$

\title{
Degradation and preservation practices of information resources in academic libraries in Cross River State, Nigeria
}

\author{
Frederick Oman Ogar, $P h D$., \\ The University Library \\ Cross River University of Technology \\ Calabar, Nigeria \\ E-mail: frederickogar@yahoo.com \\ Cell: +2347031261596
}

\begin{abstract}
The purpose of this study was to study investigate degradation and preservation practices of information resources in academic libraries in Cross River State, Nigeria. It examined the nature and causes of degradation of information resources, strategies used in their control, and constraints limiting effective preservation. The study adopted survey design. The population for the study consisted of all information resources in the five academic libraries in the state. Purposive sampling technique was used in selecting 202 respondents who supplied the information used for the study. A structured questionnaire was used for data collection and the data were analyzed using $t$-test. The result of the analysis showed that all the four null hypotheses were rejected. This means that the nature of information resources degradation in academic libraries in Cross River State is significantly high. The study also revealed that barriers to effective preservation of information resources in academic libraries in Cross River State are significantly high. Based on the findings, the study recommended among others that academic libraries should recruit adequate and trained manpower in the libraries for effective preservation programmes and activities. Academic libraries should consider various methods that could be applied to curb degradation of information resources in their holding. And,adequate annual budget allocation should be provided for preservation programmes in academic libraries in the state.
\end{abstract}

Key words: Degradation, preservation practices, information resources, academic libraries and preservation

\section{Introduction}

Generally, resources in academic libraries are regularly used and so, need constant and steady revisiting, maintenance and repairs to continuously keep them in good condition for the users to make use of them. Preservation and conservation of library resources is a serious predictor to effective service delivery in academic libraries, and so must be kept in good condition always

The purpose and function of an academic library is to acquire, organize, preserve and make accessible information resources in various formats to meet the needs of its patrons. These information materials which carry recorded human knowledge expressed the intellectual and cultural life of a given time and place needs to be preserved and conserved for future uses. Ogar (2012) noted that degradation of information resources is not a new development, but attempts are being made by librarians to minimize it by protecting the intellectual contents in the library by preserving them. Information resources in the library must be taken care of or else they would deteriorate rapidly.

Preservation is defined in the IFLA Principles for the Care and Handling of Library Material to include all the managerial and financial considerations including storage and accommodation provisions, staffing levels, policies, 
Frederick Oman Ogar: Degradation and preservation practices of information resources in academic libraries in Cross River State, Nigeria

techniques, and methods involved in preserving library and archival material and the information contained in them (IFLA, 2010). Oluwaseun, Ottong and Ottong (2017) on their part see preservation as the appropriate housing, protection, care and maintenance of archives, records and manuscripts. It should be taken seriously in order to preserve the cultural, social and technical context of our heritage.

Preservation of deteriorating information resources in libraries has become a global phenomenon to which academic libraries must aggressively respond if their mission of providing information needs of their patrons is to be achieved in this era of dwindling budgetary allocation to libraries couple with the present economic recession. The aim of information resources preservation programs is to maintain and preserve information materials according to their use and their significance. Preservation of information resources is an important aspect of library and information management. Their importance and necessity are more paramount in countries where resources are limited and libraries need to balance them with the needs of an ever increasing number of users hoping to use them.

Degradation of information resources in academic libraries have been established in literature as a universal phenomenon. While these resources are negatively affected by natural and human factors, observations and experience have shown that they are more vulnerable to decay and damage by climatic and environmental factors in academic libraries in Cross River State. Ogar (2012) noted that degradation of information resources, especially the print materials have been in existence for some decades but have escalated drastically. $\mathrm{He}$ added that Librarians and information practitioner must declare a state of emergency on the rate of degradation of their collections, in other to retard the level of degradation. However, in spite of the awareness and technological advancement in the field of preservation there seems to be more materials degrading.

The essence of this work by the author is to pin-point on the degradation and preservation practices of information resources which is very important in academic libraries. Of course, this paper will be able to recommend some practices if there is non-practiced in the academic libraries under study.

\section{Objectives of the study}

The study set out to:

1 examine the nature of information resources degradation in academic libraries in Cross River State, Nigeria;

2 determine the causes of degradation of information resources in academic libraries in Cross River State, Nigeria;

3 identify the preservation practices of information resources in academic libraries in Cross River State, Nigeria;

4 identify the barriers that hinder the preservation of information resources in academic libraries in cross River State, Nigeria; and

5 proffer solutions to the barriers identified.

\section{Research questions}

The following questions were answered in the study:

1. What is the nature of information resources degradation in academic libraries in Cross River State, Nigeria?

2. What are the causes of information resources degradation in academic libraries in Cross River State, Nigeria? 
Frederick Oman Ogar: Degradation and preservation practices of information resources in academic libraries in Cross River State, Nigeria

3. What are the practices used in the preservation of information resources in academic libraries in Cross River State, Nigeria?

4. What are the barriers hindering effective preservation of information resources in academic libraries in Cross River State, Nigeria?

5. What are the solutions to the barriers identified?

\section{Hypotheses}

The following hypotheses were tested in the study:

1. The nature of information resources degradation in academic libraries in Cross River State is not significantly high.

2. The causes of degradation of information resources in academic libraries in Cross River State are not significantly high.

3. The preservation practices of information resources in academic libraries in Cross River State are not significantly high.

4. The barriers to effective preservation of information resources in academic libraries in Cross River State are not significantly high.

\section{Literature review}

The degradation of information resources especially the paper-based records in libraries are not a discovery of our time nor are the identification of its cause new. It has been noticed since libraries began, but has accelerated to an alarming proportion from 1969 to the $21^{\text {st }}$ century. As Muhammad (2006) puts it everything in the library collection is degrading today, was degrading yesterday, and will continue to degrade tomorrow, although we ought to retard the process. A survey of literature on degradation and preservation has predicted that all paper-based records of this century as well as those of earlier years face imminent degradation. Alegbeleye (2002) argues that libraries and archives are prone to degradation that can be classified broadly as natural and manmade which include fire, flooding, civil unrest, earthquake, volcanic eruption, war, lightening and to some extent rodents and parasite attacks. On this regard, he concluded that the usefulness of preservation cannot be overemphasized in our libraries today.

Academic libraries today face a lot of problems owing to the deterioration and degradation of their collections at varying levels. Notable among these problems is the fact that library collection, especially paperbased, are acquired without allocation of adequate resources such as human and financial, to address their future degradation. Most library managers fail to realize that preservation of information resources is a component of the issues they have to contend with. In addition, no training is given to the staff and there is a generally low awareness about preservation issues especially on the corruptible tendencies of information materials and what could be done to prevent their degradation (Ogar 2012). He added that, in some cases, libraries do not have preservation policies and as a result there is neither preservation plan nor program to ensure safekeeping of library resources.

According to the National Library of Australia (2004), one of the major crises facing libraries throughout the world is the rate of deterioration of their collections. Since information resources are composed primarily of organic materials, they are subject to natural deterioration. Most libraries' collections today are based on paper - either in book or sheet form - bound volumes, newspapers, serials, manuscripts, maps, water colours, prints and drawings. Some libraries have an important collection 
Frederick Oman Ogar: Degradation and preservation practices of information resources in academic libraries in Cross River State, Nigeria

of oil paintings, a small collection of objects, and a large collection of photographic materials including negatives, prints, glass negatives and photographic albums. The collections of modern materials such as sound tapes and electronically stored information such as CD ROMs and computer discs is growing rapidly and almost all of most libraries' collections are essentially impermanent (National Library of Australia, 2004). Unlike museum items that are rarely handled, information resources are meant to be used. They are vital sources of information which cannot be conserved and stored away in an ideal and secure environment to arrest their decay. This is the dilemma of library preservation to make information accessible, while still ensuring its ultimate survival. As the IFLAPAC China Centre (2006) puts it: the core activity on preservation and conservation is to ensure that significant library and archive materials, published and unpublished, in all formats, will be preserved in accessible form for as long as possible.

Degradation of information resources is a challenge in most academic libraries. In most Nigerian libraries today, preservation is not taken seriously until most information resources starts showing traces of degradation. According to Reed-Scott (2000), libraries currently face the intellectual problems of determining what should be preserved and what should deteriorate. Preservation problems are pushing collection managers into a more activist role, in which they must make crucial preservation decisions thus growing awareness in the past decade of the magnitude of preservation problems which has resulted in a steady increase of preservation programs within research, academic, and public libraries. Efforts must be made by librarians to unsure that these valuable resources are well preserved for future generations to avoid extinction.
Regardless of the chemical constituents, all information resources will decay since the organic matter of which most libraries are made of, decay with time. Degradation of information resources is essentially the deterioration of cellulose since most of the materials are composed of namely paper, parchment, palm leaves, birch bark, leather and adhesive used in book binding and others (Maravilla 2008). The problem of degradation has several interrelated causes, Muhammad (2006) identified four factors to include: Inherent chemical instability of the component of the information resource; unstable environmental conditions in areas where collections are stored; inappropriate storage and handling practices; and disasters. Aina (2004) on his part observed that there are many causes of information resources degradation or damage, which he said many be classified into four factors to include: environmental factors, biological factors, human factors and other factors. Bankole (2010) in a review of biological degradation of information resources and possible control strategies in the tropics stated that the causes of information resources degradation can be grouped into two types: the abiotic and biotic factors. The abiotic factors are the chemical, mechanical and incidental degradation, while the biotic is the biological degradation caused by living agents. However, it is pertinent to note that chemical, mechanical and biological agents act in co-association, ranging from synergistic to antagonistic, to deteriorate the materials. Akussah (1991) in Ogar(2012) affirm that even fragile materials that are well handled could have durability. Bankole (2010) observed that, high temperature and relative humidity of the tropics contributes to the acceleration rate of various kinds of degradation. Ogar (2012) identified the factors responsible for paper degradation to include insects, rainfall, 
Frederick Oman Ogar: Degradation and preservation practices of information resources in academic libraries in Cross River State, Nigeria

mould/mildew, atmospheric pollutants, excessive heat, low relative humidity and acidity in Nigerian state libraries. Sawant (2014) states that the external causes of information resource degradation include: poor handling or storage, theft or vandalism, fire and flood, pasts, pollution, light, incorrect temperature and relative humidity (RH).

According to Lee, Slattery, Tang and McCarry (2002) techniques for the preservation of digital information include technology preservation, preservation emulation, information migration, and encapsulation. Digital resources can be stored on any medium that can represent their binary digits or bits, such as a CDROM or a DVD. Rothenberg (1995) cited in Ogar, (2012), defines a bit stream as an intended meaningful sequence of bits with no intervening spaces, punctuation, or formatting. To preserve that bit stream, the first requirement is to ensure that the bit stream is stored on a stable medium. If the digital medium deteriorates or becomes obsolete before the digital information has been copied into another medium, the data will be lost. Therefore, digital preservation involves copying the digital information into newer media before the old media becomes obsolete.

Preservation and conservation practices are focused at ensuring that significant library and archive materials, published and unpublished, in all formats are preserved in accessible form for as long as possible (IFLA-PAC China Centre, 2006). Preservation and conservation is the practice of minimizing or reducing the physical and chemical deterioration of documents. Jordan (2003) describes preservation and conservation as an umbrella term for an array of activities, principles, practices, and organizations that ensure the usability, longevity, and accessibility of recorded knowledge. These activities include; general collections repair, reformatting (microfilming, photocopying, and digitization), environmental monitoring and control, care and handling of materials, disaster preparedness and recovery, binding and preservation education and training.

In preservation, consideration is given to every element that promotes the protection of the materials including the housing, stable environment, storage system and security against such threats as theft, mutilation, disaster preparedness such as floods, fires, tornadoes, and earthquakes and poor handling. Preservation is, therefore, a more embracing concept while conservation can be described as the direct physical intervention arresting or slowing down deterioration of information resources which could be characterized as both preventive and interceptive (Ngulube, 2003; Ogunmodede \& Ebijuwa, 2013). Njeze (2012) in her study on deterioration of information resources in University libraries in South-West Nigeria found that there was high rate of deterioration in the studied universities, some of which are caused by wear and tear, dust particles, Bad shelving and biological agents. It therefore becomes imperative for a study on preservation and conservation to be carried out in the above said universities to savage the situation in the midst of this dwindling budgetary allocation to libraries in Nigeria. It is against this backdrop that this study investigates the preservation and conservation of information resources in university libraries in South-West, Nigeria.

Muhammad (2006) study identified the following as preservation and conservation practices of information resources: Environment control and monitory practices; care and handling practices (Good housekeeping, storage, handling and usage, dusting, and shelving of materials); security of the information resources practices; 
Frederick Oman Ogar: Degradation and preservation practices of information resources in academic libraries in Cross River State, Nigeria

microfilming/reformatting practices; digitization practices; photocopying practices; de-acidification practices; library binding and book repairing practices; encapsulation and lamination practices; and disaster preservation and mitigation practices.

Olatokun (2008) observed that the greatest constraint against effective preservation and conservation of information resources is inadequate funding. This is supported by Neil (2003) that digital preservation is poorly funded in relation to the scale of the challenge. He noted further that institutional libraries receive little or no additional core funding to address digital preservation. Other constraints that affected the libraries were administrative bottlenecks and harsh environmental conditions that accelerate information resources depreciation. This is confirmed by Feather (1996) that the demand for increase in the temperature in buildings has affected libraries as it does other places. Varlam off (2005) also advocated the right type of buildings for housing library holdings. UNESCO(2000) states that these agents of rapid deterioration and decay of information materials add more to the costs associated with conservation and restoration of information materials in African libraries, archives and records offices.

Lack of manpower and other infrastructure are some of the challenges facing effective preservation of information resources in developing countries. Ngulube (2001) observed that for any preservation and conservation programme to succeed in libraries and archives there must be adequate and well-trained manpower. This is because preservation and conservation of information resources is a specialized field of knowledge that requires information professionals who understand the physical and chemical nature of thematerials in their library and archive holdings. Popoola (2003) advocates the need to expose librarians and archivists to conservation and restoration practices during their training. He suggests that such a training programme should include, operating environmental control, storage and housing, operating environmental systems, designing new buildings or renovation of buildings. ESARBICA (2002) opine that lack of suitable or inadequate equipment and materials contributes significantly to the present poor status of preservation and conservation of information materials in African libraries, archives and information centers. Some of the essential materials and equipment required for setting up functional conservation and restoration laboratories in African libraries and archives are not available locally.

Other constraint against effective preservation of information resources includes low paper quality and Ink, lack of preservation and conservation policy and unfavourable government economic policies. The economic policies of most African governments do not favour library and archival services, so preservation and conservation activities are not given the priority attention they deserve. Such economic policies include those concerning high duties and tariffs charged on imports of preservation and conservation equipment. Olatokun (2008) noted that most African countries do not have a national information policy which makes the formulation of preservation and conservation policies in the libraries and information centers out of the question.

\section{Methods}

The study adopted the survey design. The population of the study is made up of all information resources in academic libraries in Cross River State. But the data used for the study are supplied by library staff of these academic libraries because they were 
Frederick Oman Ogar: Degradation and preservation practices of information resources in academic libraries in Cross River State, Nigeria

in the best position to give all the necessary information concerning the issues being considered in the study. Purposive sampling technique was adopted in selecting samples used for the study. Thus, a total of two hundred and two (202) library staff was drawn from the five academic libraries in Cross River State, Nigeria (.comprising 71 for University of Calabar Library; 52 for Cross River University of Technology Library; 53 from Federal College of Education, Obudu; 11 for Cross River College of Education and 15 for Cross State College of Health Technology, Calabar. Two hundred and two (202) questionnaires were administrated to the library staff in the five academic libraries in Cross River State and one hundred and ninety six (196) were returned. Four (4) of the returned questionnaires were rejected because they were not completely filled. Only one hundred and ninety two (192) questionnaires $(95 \%)$ were used for analysis. Table 1 presents a list of the selected staff and the academic libraries. A structured questionnaire was used for data collection and the data was analyzed using population $t$ - test.

Table 1: Distribution of population of study according to institution

\begin{tabular}{|c|c|c|c|c|}
\hline $\mathbf{S} / \mathbf{n}$ & Institution & Librarians & $\begin{array}{l}\text { Population } \\
\text { Paraprofessional }\end{array}$ & Total \\
\hline 1 & $\begin{array}{l}\text { University of Calabar Library, } \\
\text { Calabar }\end{array}$ & 12 & 59 & 71 \\
\hline 2 & $\begin{array}{l}\text { Cross River University of } \\
\text { Technology Library, Calabar }\end{array}$ & 7 & 45 & 52 \\
\hline 3 & $\begin{array}{l}\text { Federal College of Education of } \\
\text { Library, Obudu }\end{array}$ & 10 & 43 & 53 \\
\hline 4 & $\begin{array}{l}\text { Cross River College of Education } \\
\text { Library AwiAkamkpa }\end{array}$ & 5 & 6 & 11 \\
\hline 5 & $\begin{array}{l}\text { Cross River College of Health } \\
\text { Technology Library, Calabar }\end{array}$ & 4 & 11 & 15 \\
\hline & Total & 38 & 164 & 202 \\
\hline
\end{tabular}

\section{Results}

Hypothesis 1: The nature of information resources degradation in academic libraries in Cross River State is not significantly high.
In this hypothesis the only variable is the nature of information resources degradation. Using the population $t$-test, the result obtained is presented in table 2 below. 
Frederick Oman Ogar: Degradation and preservation practices of information resources in academic libraries in Cross River State, Nigeria

Table 2: $t$-test analysis of the nature of information resources degradation in academic libraries in Cross River State

Nature of information resources

degradation in academic libraries

Observed

$\mathrm{N}$

$\overline{\mathrm{X}}$

SD

$t$-cal.

33.13

6.18

192

$74.29 *$

Expected

35.00

6.18

*Significant level 0.05 level, df $=191, t$ critical $=1.96$

From the above table, the calculated value of $t=74.29$ is greater than the critical value of 1.96 at 191 degrees of freedom and 0.05 level of significant under two tailed test. With this result the null hypothesis is rejected. This implies that the nature of information resources degradation in academic libraries is significantly high in Cross River State.

Hypothesis 2: Thecauses of degradation of information resources in academic libraries in Cross River State is not significantly high.

The only variable in this hypothesis is causes of degradation of information resources. Using the population $t$-test statistical analysis, the result obtained is presented in Table 3.

Table3: $t$-test of the causes of degradation of information resources in academic libraries in Cross River State

\begin{tabular}{lcccc} 
Causes of information resources degradation & $\mathrm{N}$ & $\overline{\mathrm{X}}$ & $\mathrm{SD}$ & \multicolumn{1}{c}{$t$-cal } \\
\hline Observed & & 38.74 & 8.11 & \\
& 192 & & & \\
Expected & & 37.5 & 8.11 & \\
\hline
\end{tabular}

*Significant level 0.05 , df $=191, t$-critical $=1.96$

Table 3 above shows that the calculated $t$-value of 66.22 is greater than the critical value of 1.96 at 191 degree of freedom and 0.05 level of significance under two tailed test. Based on this result, the null hypothesis is rejected. Indicating that the causes of degradation of information resources in academic libraries is significantly high in Cross River State.

Hypothesis 3: The preservation practices of information resources in academic libraries in Cross River State are not significantly high.

The only variable in this hypothesis is preservation practices of information resources. To analyze this hypothesis population, $t$-test was used and the result obtained is presented in table 4 . 
Frederick Oman Ogar: Degradation and preservation practices of information resources in academic libraries in Cross River State, Nigeria

Table 4: t-test analysis of the preservation practices of information resource in academic libraries in Cross River State

$\begin{array}{lllll}\text { Preservation practices } & \mathrm{N} & \overline{\mathrm{X}} & \mathrm{SD} & t \text {-crit. } \\ \text { Observed } & & 25.07 & 4.69 & \\ \text { Expected } & 192 & 24.00 & 4.69 & 72.91^{*}\end{array}$

*Significant level $0.05, \mathrm{df}=191, t$-critical $=1.96$

The result in table 4 revealed that the observed $t$-value of 72.91 is greater than the critical value of 1.96 at 191 degree of freedom and 0.05 level of significant under two tailed test. From the findings the null hypothesis is rejected. Therefore the alternative hypothesis is retained, which indicates that the preservation practices of information resources in academic libraries is not significantly high.

Hypothesis 4: The barriers hindering effective preservation of information resources in academic libraries in Cross River State are not significantly high.

The only variable in this hypothesis is barriers hindering effective preservation of information resources. Using population ttest statistical technique in analyzing the hypothesis, the result obtained is presented in table 5.

\section{Table 5: t-test analysis of significant influence of barrier to effective preservation of information resources in academic libraries in Cross River State}

\begin{tabular}{|c|c|c|c|c|}
\hline $\begin{array}{l}\text { Barriers hindering effective preservation } \\
\text { practices of information resources }\end{array}$ & $\mathrm{N}$ & $\bar{X}$ & $\mathrm{SD}$ & $t$-cal. \\
\hline \multirow[t]{2}{*}{ Observed } & & 21.05 & 3.82 & \\
\hline & 192 & & & $76.43 *$ \\
\hline Expected & & 17.5 & 3.82 & \\
\hline
\end{tabular}

*Significant level 0.05, df. $=191, t$-critical $=1.96$

The finding in Table 5 revealed that, barriers to effective preservation of information resources in academic libraries is significantly high. From the analysis the calculated t-value of 76.43 is greater than the critical $t$-value of 1.96 at 0.05 level of significance and 191 degree of freedom under two tailed test. With this analysis the null hypothesis is rejected and the alternative hypothesis is retained.

\section{Discussion}

On the issue ofthe nature of information resources degradation,the analysisrevealed that degradation of information resources in academic libraries is significantly high in Cross River State. The finding is in line with the views of Abioye (2009), that the challenges of degradation of information resources in academic libraries are enormous and require urgent attention without this the hope of sustaining and 
Frederick Oman Ogar: Degradation and preservation practices of information resources in academic libraries in Cross River State, Nigeria

propagating knowledge to generations yet unborn is not achievable. Maidabino and Zainab(2011)observed that incidents of theft, wearing and tearing due to excessive use, excessive light, non-return of materials, mutilation and other forms of degradation of library stock are on the increase depending on the nature of the materials. Lorenzen (1996) cited in Ogar (2012) also stated that periodic deterioration of information resources is a big constraint for both public and academic libraries.

Observation shows that information resources are bound to deteriorate with time through the aging process and to replace them maybe difficult and expensive if not practically impossible. The modern day academic library is faced with the problem of degradation of her holdings due to lack of awareness of preservation and conservation by both staff and users. Sometime the staffs are not ready to do their work, thereby aiding users to mutilate and vandalize the information resources for their selfish gain.

The analysis on the causes of degradation of information resources, the result showed that causes of degradation of information resources in academic libraries is significantly high in Cross River State. This finding corroborates the view of Bankole (2010) that high temperature and relative humidity of the tropics contributes to the acceleration rate of various kinds of degradation. Momoh (1987) cited by Ogar (2012)also identified the factors responsible for high information resources degradation to include insects, rainfall, mould/mildew, atmospheric pollutants, excessive heat, low relative humidity and acidity in Nigerian state libraries.

On the preservation practices of information resources in academic libraries, the finding revealed that the practices and techniques of preservation of information resources in academic libraries is significantly high. This finding is supported by Muhammad (2006), Bamigboye and Buraimo (2008) who identified proper environmental control and monitory, proper housekeeping practices, security of the information resources, proper storage of information resources as the best effective measure of preservation practices. Sawant (2014) noted that continuing program of cleaning shelves and information resources helps to control the amount of air borne dirt, Bendix and Walker (2011) also pointed out that good air circulation in the library helps to reduce mould growth in information resources. The issue of preservation is anchored on attitudinal change by both staff and users towards information resources in our academic libraries and the awareness of the various preservation practices by them.

The analysis on the barriers hindering effective preservation of information resources, the analysis revealed that barriers to effective preservation of information resources in academic libraries in Cross River State are significantly high. This result is in line with the opinion of Mnjama and Wamukoya (2004) and Muhammad (2006). They observed that preservation and conservation of information resources constitutes a big challenge to libraries worldwide. Muhammad in his view said the challenge of material preservation in the tropics seems to be overwhelming due to a number of factors which he identified to included harsh tropical environment, lack of funding, shortage or absence of skill manpower, absence of preservation policy and general lack of preservation awareness and appreciation of important sensitivity of information resources. UNESCO (2000) and Popoola (2003) also observed that environmental factors are agents of rapid degradation and decay of information materials, adding more to the cost associated with conservation and restoration of information materials in African libraries, archives and records offices. The greatest 
Frederick Oman Ogar: Degradation and preservation practices of information resources in academic libraries in Cross River State, Nigeria

constraint against effective preservation and conservation of information resources is inadequate funding.

\section{Conclusion}

One of the major problems associated with academic libraries in Cross River State is the continuous degradation of its information resources which in turn appears to be affecting the state of their effectiveness in the provision of services. This in effect constitutes the emerging challenges as well as issues affecting academic libraries in Nigeria and the world over in service delivery. It is apparent that the current fight to achieve information resources degradation free environment in academic libraries appears to be totally placed in sound implementation of appropriate preservation and conservation policies and practices. But it does appear as if there are no concerted efforts at creating awareness about information resources degradation and its preservation, for librarians, information scientist, library staff as well as users, as workshops, conferences and seminars organized also appears to be grossly inadequate for sustainable information preservation. If adequately redressed the trend would stir up and expand the volume of the information resources in these libraries, and the adoption of appropriate preservation practices and policies would be the hallmark of great academic libraries. The size of the academic library collection may not be the benchmark but accessibility to needed information resources by users in good condition and at the right time.

Based on the findings, the following recommendations are made:

1. Adequate and trained manpower should be recruited by academic libraries for preservation programmes and activities to succeed because preservation and conservation activities are specialized and require information professionals who understand the physical and chemical nature of the materials in their library holdings.

2. Academic libraries should consider various methods that could be applied to curb degradation of information resources in their holding.

3. Appropriate instruction should be developed for monitoring good housekeeping practices and also inappropriate use of information resources by staffs and users should be discourage.

4. Since the study established that there is high incidences of degradation of information resources, the academic libraries should not only strive to acquire information resources but should ensure that the materials acquired are preserved and conserved in a usable condition for generation of users.

5. That library managers and librarians should show more interest in the area of preservation and conservation of information resources in their custody to prevent them from degradation.

6. Academic libraries should embark on periodic in-house training programmes by way of workshops, conferences, seminars etc for the purpose of skill acquisition for the library's staff.

7. Adequate annual budget allocation should be provided for preservation programmes by the makers. The budget should be all encompassing, that is, it should be for funding, training, infrastructure and other constraints that may hinder preservation activities. 
Frederick Oman Ogar: Degradation and preservation practices of information resources in academic libraries in Cross River State, Nigeria

\section{References}

Abioye, A. (2009). Issues and approaches to the degradation and preservation of paper and microform in Nigeria: A paper presented at the workshop on National policy in preservation and conservation of national documentary heritage in Nigeria. NCCE Conference room Abuja 24 $-27^{\text {th }}$ March.

Aina, L.O. (2004). Library and information science text for Africa. Ibadan: Third World Information Service Ltd.

Alegbeleye, B. (2002). Preservation and conservation: rationale, procedure, trends and benefits for research and scholarship. Being paper presented at the seminar on preservation for posterity. Organized by National library of Nigeria and UNESCO $4^{\text {th }}$ June.

Bamigboye, O.B. \& Buraimo, O.K. (2008). The preservation of information resources. The case of Olabisi Onabanjo University Library, AgoIwoye and Akenneth Dike Library, University of Ibadan. Ibadan Nigeria .Delta Library Journal. 2 (1\&2), 113

Bankole, O.M. (2010). A review of biological degradation of information resources and possible control strategies in the tropics. Library Review.59 (6), 414-429.

Bendix, C. \& Walker, A. (2011).Cleaning books and documents. London. British Library.

ESARBICA. (2002). Minutes of the ESARBICA executive board meeting held at the mountain lun. Mbabane, Swaziland. March 11-13.

Ezennia, S.E. \& E.O. Onwuka. (1995). The battle for preservation of information materials in Nigeria. Library and Archival Security 13(1), 29-39.
IFLA (2010).Principle for the care and handling of library materials. International preservation Issues. 1. Retrieved from http//archive.ifla.org /VI/news/pchlm.

IFLA-PAC China centre (2006). Strategic plan 2006-2008. Retrieved from http://www.nlc.gov.en/services/flpac chinacentre/strategem.htm.

Jordan K.S. (2003). Special collections and preservation: In Encyclopedia of library and information science. Chicago, Illinois USA: Chicago Public Library.

Lee, K; Slattery, O; Lu, R; Tang, X. \& McCarry, V. (2002). The state of the art and practice in digital preservation. Journal of Research of the National Institute of Standards and Technology 107(1), 20-31.

Lorenzen, M. (1996).Security issues of academic libraries. ERIC Document. No.ED39676.

Maidabino, A.A. \& Zainab, A.N. (2011). Collection Security Management at University Libraries: Assessment of its Implementation Status. Malaysian Journal of Library \& Information Science 16 (1),15-33.

Maravilla, N.R. (2008) cause of degradation of paper. Retrieved from http://www.cool.Conservation US.org/byauth/maravilla/degradatio n- causehtml.

Mnjama, N. \&Wamukoya, J. (2004).Egovernment and e-records management.A paper presented at the SADC workshop on Egovernment. Gaborone, Botswana. $14^{\text {th }}-16^{\text {th }}$ April

Muhammad, U.N. (2006). Preservation and conservation of information resources: The situation in the National library of Nigeria. Nigerbiblios. 17 (1\&2), 116-139. 
Frederick Oman Ogar: Degradation and preservation practices of information resources in academic libraries in Cross River State, Nigeria

National Library of Australia (2004). Preservation policy. Retrieved from http://www.nla.gov.au/policy/pres html.

Neil, B (2003). Study on National Digital Preservation Initiatives. Council on library and Information and Library of Congress. Retrieved from http://www.clir.org/pubs/report/pubs 116/content.html.

Ngulube, P. (2001). Guidelines and standards for records management education and training: a model for Anglophone Africa. Records Management Journal 11(3), 155173.

Ngulube, P. (2003) Preservation and access to public records and archives in South Africa. Unpublished doctoral thesis submitted to the School of Human and Social Studies, University of Natal, Pietermaritzburg. Retrieved from http://www.infs.ukzn.ac.za /the sispn.pdf.

Njeze, M. E. (2012). Preservation and conservation issues in selected private universities in South-West Nigeria. Library Philosophy and Practice. Retrieved from http://digit alcommons.unl.edu/libphilprac/761. .

Ogar, F.O. (2012). Degradation and preservation practices of information resources in academic libraries in Cross River State, Nigeria. Unpublished master's thesis carried out in the Department of Library and Information Science University of Calabar. Nigeria.

Ogunmodede, T.A. \& Ebijuwa, A.S. (2013) Problems of conservation and preservation of library resources in african academic libraries: A review of literature. Greener Journal of Social Sciences. 3(1), 050-057.
Retrieved from http://www.gjournal s.org.

Olatokun, W.M. (2008). A survey of preservation and conservation practices and techniques in Nigeria university libraries. Library and Information Science Research Electronic Journal. 18(2), Retrieved from http://www.libres. curtin.edu.au /.

Oluwaseun, A; Ottong, E.J.; and Ottong, U.J. (2017) "Preservation of Library Resources in Nigeria Universities: aStudy of Collections in Cross River State Universities. Communications of the IIMA:/ 15(3). Retrieved from http://scholarworks.lib.csusb.edu/cii ma/vol15/iss3/4 16 ${ }^{\text {th }}$ October, 2019

Popoola, S.O. (2003). Preservation and conservation of information resources. Ibadan: Distance Learning Centre.

Reed-Scott, J. (2000). Planning for preservation in libraries. In: Banks, P.N., \& Pilette, R. (Eds). Preservation: Issues and planning. Chicago: American Library Association, pp.82-96.

Sawant, S. (2014). A study on preservation and conservation practices in academic libraries in Mumbai. Annals of Library and Information Studies.16.153-159.

UNESCO (2000). Safeguarding our documentary heritage. Retrieved from http://webworld.unesco.org/

Varlamoff, M. (2005) The first step in preservation: building the right building. Paper presented at the World Library and Information Congress: 71st IFLA General Conference and Council "Libraries A voyage of discovery" August 14th 18th 2005, Oslo, Norway. Retrieved from http://www.ifla.org/IV/ifla71 /papers/100e-Varlamoff.pdf. 